\title{
Urban planning with respect to environmental quality and human well-being
}

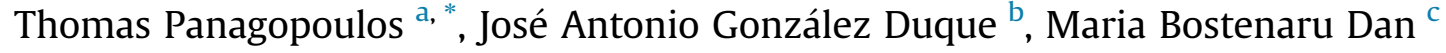 \\ ${ }^{a}$ Centro de Investigação Sobre Espaço e Organizações (CIEO), Algarve University, Campus de Gambelas, 8005-139 Faro, Portugal \\ ${ }^{\mathrm{b}}$ Department of Agroforestry Science, Escuela Politécnica Superior, Huelva University, Campus de La Rábida, 21819 Palos de La Frontera, Huelva, Spain

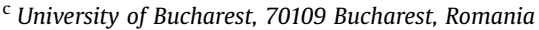

\section{A R T I C L E I N F O}

\section{Article history:}

Received 12 May 2015

Received in revised form 17 July 2015

Accepted 23 July 2015

Available online 1 August 2015

\section{Keywords:}

Well-being

Urban planning

Green infrastructure

Environmental quality

\begin{abstract}
A B S T R A C T
The cities of today present requirements that are dissimilar to those of the past. There are cities where the industrial and service sectors are in decline, and there are other cities that are just beginning their journey into the technological and industrial sectors. In general, the political and social realms have been restructured in terms of economics, which has resulted in an entirely different shape to the primitive structures of civilization. As people begin to understand the dynamic nature of landscapes, they stop seeing landscapes as a static scene. Sustainable cities must be simultaneously economically viable, socially just, politically well managed and ecologically sustainable to maximize human comfort. The present research suggests a multi-disciplinary approach for attaining a holistic understanding of urban environmental quality and human well-being in relation to sustainable urban development.
\end{abstract}

() 2015 Elsevier Ltd. All rights reserved.

\section{Introduction}

The urban habitat can be aggressive and unnatural for human beings. In many cities, urban green spaces may be missing or poorly distributed. Urban planning must take into account the noise pollution produced by cars and household heating systems. The heat island effect in urban areas and conurbations must also be considered. Socio-spatial variations in urban environmental quality and human well-being are not new subjects; rather, they are an established characteristic of city life (Fig. 1). Cities have always represented a mixed bag of blessings and downfalls for their inhabitants (Pacione, 2003a,b). Other important factors may contribute to quality of life in urban areas, such as accessibility to green areas and whether such destinations can be reached in ways beyond the usual means of transport, namely by bicycle or on foot (Jankovska et al., 2013). Suburban areas, if well designed, may contribute to well-being (Cameron et al., 2012).

Air is among the most important environmental factors in the relationship between environmental quality in inhabited areas and population health and welfare. Green spaces contribute to the

\footnotetext{
* Corresponding author.

E-mail addresses: tpanago@ualg.pt (T. Panagopoulos), duque@uhu.es (J.A. González Duque), Maria.Bostenaru-Dan@alumni.uni-karlsruhe.de (M. Bostenaru Dan).
}

quality of the air, which needs to be monitored for pollution. Laws regarding both air pollution control and green space management have to be considered.

Climate change affects cities, which are increasingly recognizing the need to prepare for the impacts on their assets and residents. Some cities have seen notable changes in relation to the frequency and intensity of extreme weather events; other cities have experienced changes in temperatures, while others still have experienced coastal erosions, the disappearance of wetlands and storm surges (Carmin et al., 2012). It is important for stakeholders to know what to expect so that the necessary structures can be developed in the phase of preparation and organization (Karanikola et al., 2014). Many cities are working on adaptation and planning strategies. To this extent, ecosystem services provide a number of mitigation functions. Although it is necessary to share a methodology for and knowledge about different forms of landscapes or a theoretical foundation, the key is a common frame of reference that has a reasonable fit with the range of ways in which disciplines and communities perceive and value landscapes (Stephenson, 2008).

The present research suggests a multi-disciplinary approach for attaining a holistic understanding of urban environmental quality and human well-being in sustainable urban development. 


\section{Ecology and biodiversity}

\subsection{Ecology}

The heart of landscape ecology is the evaluation of spatial configuration and temporal sequencing as they affect landscape ecological integrity and aesthetic appeal. We believe it is the logical discipline within which to elaborate the union of these issues. This union has been called 'the landscape ecological aesthetic' (Thorne and Huang, 1991).

Natural sounds, meanwhile, may improve the quality of built-up environments to a certain extent. However, any incongruence between sound and image in a landscape quite clearly diminishes the value assigned it, indicating the need to conserve singular soundscapes. Such cases call for the application of soundscape conservation measures in protected natural spaces, cultural landscapes and parks and green areas (Carles et al., 1999). In landscape architecture, there is an approach where not only the visual element but also the auditory or tactile element is used to inspire participants to recall memories and design an outgoing landscape (Bostenaru, 2010). However, soundscape can also be negatively connoted as sound pollution.

Fragmentation is a research concept properly belonging to the biosciences and agriculture, yet it has application in the planning and design fields. Cultural landscape, in contrast, is a concept uniquely rooted in landscape architecture and resource management. Planners and designers are challenged to consider whether human actions are "natural" actions or they belong in a separate philosophical category (Taylor, 2002).

An influential paper about green walls comes from Francis and Lorimer (2011). In this study, living walls are discussed as an instrument for reconciliation ecology. Another key aspect is the promotion of public participation in urban green spaces and the contribution of green walls in urban sustainability (Bostenaru, 2014). Green walls also help improve urban health in crowded cities. When a space is not sufficient for creating green spaces, even pocket parks, green walls can make use of vertical surfaces. With this method, urban heat islands decrease in the summer, and in the winter, green walls contribute to better insulation and energy savings. In the Art Nouveau movement, architecture and biology found a common point. New developments in biology were of interest for architects, and the ornamentation of buildings was inspired by vegetal models. However, these were drawn or carved, and any combination could exist; that is, the ecological habitat composition was not necessarily followed. Today, green walls have to be grown in accordance with the climate of the city in which they are planted.

Masonry retaining walls together with their vegetative companions constitute a distinctive urban ecology in Hong Kong (Jim and Chena, 2010). Whereas humans have built the artificial cliffs in an apparently inhospitable habitat, it is nature that has provided a generous combination of abiotic and biotic factors in an

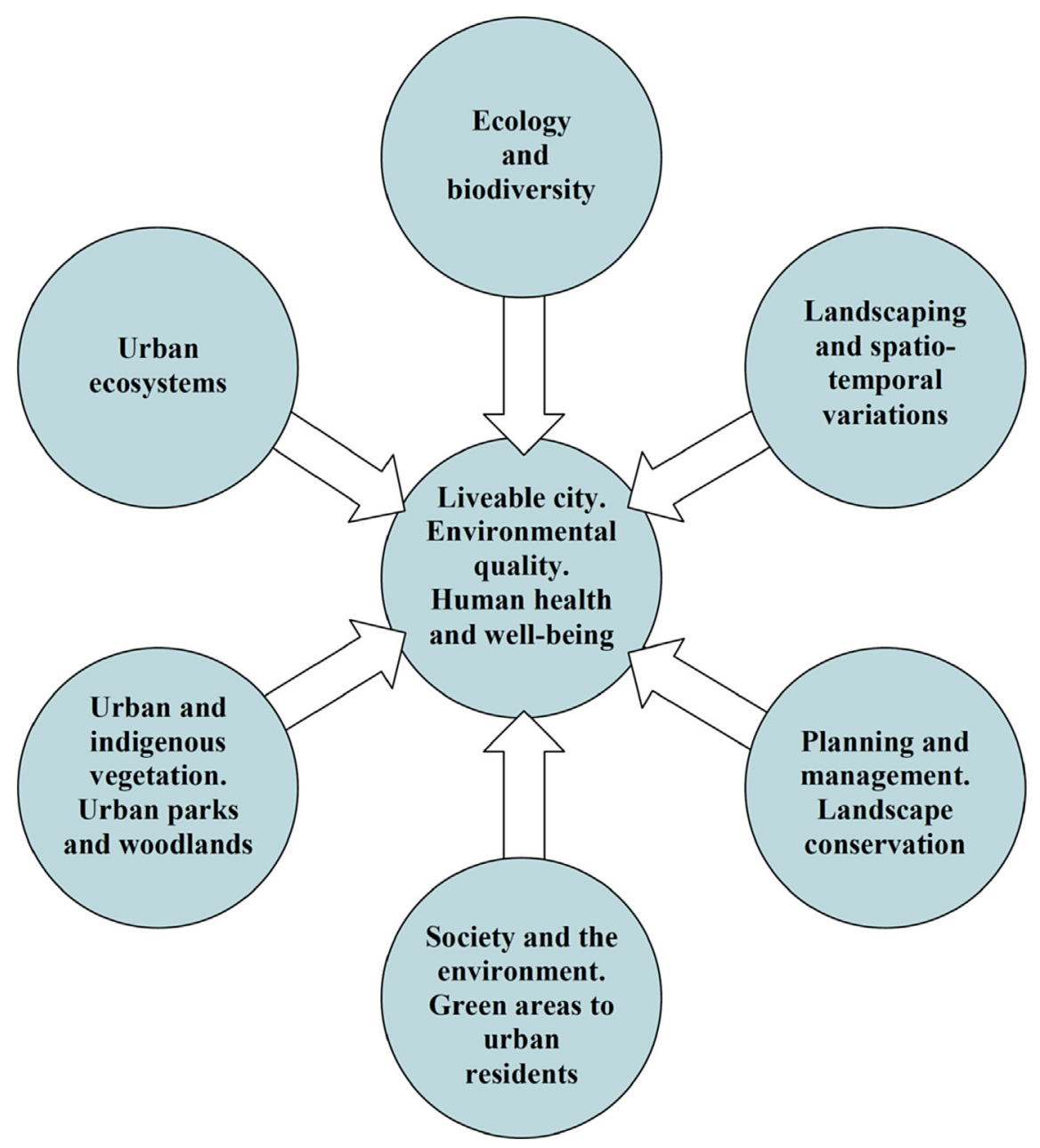

Fig. 1. Livable city and environmental quality relationships with human health and well-being. 
inordinately harsh compact city milieu, which has allowed persistent and abundant vegetative colonization. New material developments such as biodegradable geotextiles can allow growing plants on converted sites such as ash damps or garbage deposits (Siminea and Bostenaru, 2000), thereby increasing the green space but also minimizing emissions from the toxic deposits.

City soils perform a number of crucial functions that make them environmentally, economically and socially important. Which soil functions can be distinguished? Production, carrier, filter, resource, habitat, and cultural functions are usually recognized. Some of these functions are exclusive and in competition (EC, 2006). The sealing of soil can lead to a decrease in water permeability, a loss of biodiversity, and a reduction in the capacity for the soil to act as a carbon sink (Scalenghe and Marsan, 2009).

\subsection{Biodiversity}

Maintaining biodiversity requires a wise combination of protection, management and recreation of habitats to secure representative and functional habitat networks. As urbanization increases worldwide, town and cities are becoming the most common habitat for humankind. The successful maintenance of representative habitats can be viewed as a series of partly overlapping and complementary "green infrastructures" in the landscape, each of which has various properties to which species are adapted (Sandström et al., 2006).

The information on biodiversity issues that planners have at their disposal often offers very limited support. In particular, there is a lack of informative data and suitable planning support systems (Geneletti, 2008). To help prevent further loss of biodiversity, there is an urgent need for more strategic approaches to conservation planning in urban environments based on a scientific understanding of landscape patterns, species requirements and development pressures. Conservation planning tools can be better integrated into the different stages of land use planning for future urban growth (Gordon et al., 2009). Brownfield redevelopment in former industrial urban sites are a challenge due to public concerns about health effects from hazardous chemicals, but they also present an opportunity for restoration and reuse as an urban park to study ecology and augment biodiversity; however, in such situations, the planning process is not sufficiently supported, especially by the legislative process (National Geographic, 2012).

\section{Urban ecosystems}

Urban ecosystems are a complex mosaic of climates, land uses, and biophysical and socioeconomic variables. Future studies of urban forests and their role in environmental quality should consider the ecological and socio-economic heterogeneity within the urban ecosystem (Escobedo and Nowak, 2009). Ecosystem services provided by Green Infrastructure can provide healthy environments and physical and psychological health benefits to the people residing within them. Healthy environments can contribute to improved socio-economic benefits for communities (Tzoulas et al., 2007). Ecosystem quality tends to decline continuously as urban density increases. However, the scattered evidence in many of these relationships suggests that for any given urban density, with appropriate consideration to the proportion and configuration of green space and tree cover, there is substantial scope for maximizing ecological performance (Tratalos el al., 2007).

The maintenance of ecosystem goods and services, i.e., natural capital, is a basic guarantee of environmental security that aims to evaluate the level of threats to the actual flux of natural capital (Costanza and Daly, 1992). This level of threats is of particular relevance considering that in each country, there is a great number of areas that are recognized for their natural value (Petrosillo et al., 2009). When key ecological services, such as clean air and water, drought and flood protection, soil generation and preservation, and detoxification of wastes, are disrupted, the health and welfare of society are put at risk. Understanding ecosystem responses to urbanization is necessary to evaluate and balance short-term needs with long-term sustainability goals (Styers el al., 2010).

\section{Landscaping and spatio-temporal variations}

Landscaping can and should support environmental functions as well, such as conserving water and providing wildlife habitats. However, for persuasive health, social, and environmental reasons, these design elements must increasingly be incorporated within traditional and neo-traditional urban settings (Jackson, 2003). Geographical information systems (GIS) are excellent tools for landscape modeling and three-dimensional analysis. They allow easy digitalization of geographical information and coverage structures, as well as facilitate graphical representation (Hernández et al., 2004). Diachronic analysis allows us, for example, to visualize the loss of urban green space over time. (Armaş et al., 2014). In addition, combining GIS with remote sensing data may allow us to recognize patterns of change in geomorphology due to changes in land use (Armaş et al., 2014).

There is little information available on the spatial variation of landscape functions. A methodological framework has been developed to map and quantify landscape functions depending on the availability of spatial information. Making landscape functions spatially explicit adds an important component to research conducted in the field of quantifying landscape goods and services (Willemen et al., 2008). Analyzing spatio-temporal characteristics of land use change is essential for understanding and assessing the ecological consequences of urbanization. More importantly, such analysis can provide basic information for appropriate decision making (Deng el al., 2009). Space and time are intrinsic components of the decision making process in natural resource management. As such, the spatio-temporal nature of decision making should be acknowledged and incorporated into models developed to assist the management of natural resources (Bone and Dragićević, 2010).

\section{Urban parks, woodlands and indigenous vegetation}

\subsection{Urban and indigenous vegetation}

The areas of indigenous vegetation within cities and towns are mostly endangered, even when they are protected by law. It is necessary to know the endangering factors to improve the efficiency of protection in these areas and develop conservation strategies sensitive to the special qualities of the different sites (Breuste, 2004). The full range of aesthetic functions includes the visual, scenic and tactile effects of urban vegetation as well as multisensory effects (Smardon, 1988).

\subsection{Urban parks}

When internationally evaluating cities in terms of competitiveness, one major aspect to take into account is the presence of public facilities such as urban parks. Another consideration is citizen accessibility to urban parks. These notions can be viewed as differences between an industrial society, in which the primary focus is on economic efficiency and productivity, and a more culturally oriented society, where a higher quality of life is prioritized. Providing parks near neighborhoods is vital. They function as recreational areas for citizens to congregate and socialize while also 
aesthetically upgrading the vicinity (Oh and Jeong, 2007). Analysis of different parks shows that spatial articulation is a clue to spatial occupancy (Goličnik and Thompson, 2010).

People from all ethnic backgrounds spend some of their leisure time in green areas. This study found that urban parks are more inclusive green places than non-urban green areas and that urban parks can promote social cohesion. That urban parks can be used by people from different racial backgrounds and contribute to health was recognized as early as the 19th century by the forethinking landscape architect Frederick Law Olmsted (Hall, 1995). One good example in this regard is Central Park in New York, which provides green space for the residents of crowded Manhattan. Urban green areas that are designed to meet different cultural needs and facilitate social interaction may contribute to social cohesion in the culturally diverse cities and towns of late modern society (Buijs et al., 2009).

\subsection{Urban woodland}

Urban forestry research in the Nordic and Baltic countries is very diverse. Project topics range from tree selection to studies of the impacts of urban woodland and nature on human health and wellbeing. The results emphasize the importance of international research networks for the development of urban forestry research. By enhanced networking and collaboration within the research community, both across disciplines and between researchers and those commissioning and using research, urban forestry research can be strengthened and made more relevant (Konijnendijk et al., 2007).

The present concern for urban environments and the quality of life in cities, along with a scientific awareness about the role played by trees in all these aspects, has given rise to a great interest in treeplanted areas of cities. There exists a correlation between the possibilities of urban comfort and the existence of green zones, or, more accurately, the size of tree-lined or green space zones (Gómez et al., 2001).

Urban forest patches may play a role in mitigating particulate matter air pollution and should be considered in plans for improving urban air quality (Cavanagh et al., 2009). The potentials for creating urban coppice woodlands that are managed for multiple uses by local residents is an exciting prospect and one that will become increasingly in demand as the debate on nature conservation, climate change, and human health and well-being intensifies (Busse and Møllerb, 2008). Both urban parks and urban woodlands can host urban events that foster cohesion in the communities around them. Castle gardens can be included in the life of the city by organizing historic events, and thematic fairs can be held in the park.

\subsection{Urban agriculture}

A current trend in urbanism is urban agriculture. As we discussed with green walls, instead of pocket parks, unused urban land can be transformed into agricultural pockets. In the city of Pavia, rice fields can be found in the periphery of the city. Urban sprawl can be combined with urban agriculture to create agricultural landscapes (Popa, 2014; Stan, 2014) or leisure facilities for city residents. With the economic crisis reducing the pressure for construction, such areas have been converted into urban farms. Landscape planners try to upgrade the value of settlements by proposing associated urban agriculture lands with European funding.

\section{Society and the environment. Green areas to urban residents}

The interconnections between society and the environment are profound (Berte and Panagopoulos, 2014). The green areas located close to residential settings areas may be one among potential protective factors that can buffer against adverse health effects due to chronic traffic-noise exposure (Gidlöf-Gunnarsson and Öhrström, 2007). Information concerning the social value and meaning of green areas to urban residents is currently scarce. This information should be made available in a usable form for urban land use and green area planning (Tyrväinen et al., 2007).

Urban residents worldwide have expressed a desire for contact with nature, each other, attractive environments, places in which to recreate and play, privacy, a more active role in the design of their community, and a sense of community identity. The design of urban landscapes strongly influences the well-being and behavior of users and nearby inhabitants (Matsuoka and Kaplan, 2008). Today, a critical mass of research has identified human needs related to nature and the role the environment plays in providing social interaction for nearby residents (Rodiek, 2008).

Decision making must seen in all its dimensions: involving experts from different disciplines, authorities in city halls, and both the passive public and affected citizens. For the latter two, a particular case of decision making applies: public participation. Making information on developments visible is important not only for informing the public and letting people communicate their opinions but also for realizing greater environmental value through the presence of urban green space. Tom Koenigs (1991) said that the "ideas in the heads" of people protect better than legislation. Therefore, environmental education is necessary through outreach on research projects.

\section{Spatial planning, management and landscape conservation}

\subsection{Planning and management}

It is increasingly recognized that more sustainable approaches are needed for planning and managing landscapes worldwide. Currently, traditional planning of master plans for cities and regional plans has shifted from authoritative autonomous means to participative means, with the European Landscape Convention being the first international treaty to support and promote the protection, management and planning of all landscapes and raise awareness about the value of a living landscape (CE, 2000).

Soil and land use management needs to focus on sustainable use of natural capital and resources. Challenges will increase with global changes in climate and the distribution of economic power, in addition to growing societal expectations and population, so we need to steward soil resources and manage land use activities to help transition to a sustainable future (INSPIRATION, 2015). From a climatic point of view, the comprehensive planning level is very important because it provides a good view of the interaction of the different climatic effects produced by cities and surrounding rural landscapes. This information is important to understanding how changes in land use affect the local climate (Eliasson, 2000).

Unfortunately, conventional urban planning often focuses more on economic growth than on natural assets and ecological sustainability (Wang, 2009). According to Rockström et al. (2009), the goal should be "sustainable human well-being and not growth of material consumption". Analysis and planning of ecological networks are a relatively new phenomenon and a response to the fragmentation and deterioration of the quality of natural systems. In urban areas, the problems of land use intransigence and political and jurisdictional issues create a difficult environment for 
implementing ecological networks (Cook, 2002).

The spatial dimension of sustainability engages processes and relations between different land uses, ecosystems and biotopes at different scales and over time (Loures et al., 2015). It is unlikely that landscapes can ever be sustainable, except where we attempt to adopt an overtly conservationist approach (Potschin and HainesYoung, 2006).

As people begin to understand the dynamic nature of landscapes, they will cease to view the landscape as a static scene, a perspective that does not address ecological sustainability, and embrace new ecological aesthetic ideas (Panagopoulos, 2009). Landscapes change because they are an expression of the dynamic interaction between natural and cultural forces in an environment. Cultural landscapes are the result of consecutive reorganization of land to adapt its use and spatial structure better to changing societal demands.

Planning and managing future landscape remain difficult and extremely uncertain. The processes and management involved in past traditional landscapes, the manifold relations people have towards the perceivable environment and the symbolic meaning it generates offer valuable knowledge for more sustainable planning and management for future landscapes (Antrop, 2005).

\subsection{Spatial planning and landscape conservation}

Increasing urban green space, such as parks, forests, green roofs, streams, and gardens, decreases environmental pollution (Wolch et al., 2014). Strategies include greening of remnant urban land (terrain vague) and reusing obsolete infrastructure; however, the quality of soils is important for the success of such initiatives. Sealing and air pollution can affect the success of these initiatives; therefore, careful land use planning is needed to decrease sealing and particle pollution. For urban agriculture, the quality of soil is even more important, because polluted soil can affect public health (Brown and Jameton, 2000). Land use can in this case directly affect sustainability because today's use affects any eventual changes in use. Land use plans are a non-structural measure for decreasing pollution and improving sustainability.

Spatial planning and land management may have important impacts on the potential transfer of pollutants from contaminated soils to humans. For those areas where risk is identified as unacceptable, alternative planning or management options should be defined to achieve a maximal risk reduction in a cost-effective way (Poggio et al., 2008). The concept of soil quality represents the integration of the physical, biological, and chemical aspects of soils. Limited attention has been paid to the holistic assessment of soil quality in landscape and urban planning to identify soil constraints and target management practices or remediation strategies (Schindelbeck et al., 2008).

New landscapes emerge with changing lifestyles. The shape and health of the landscape legacy that we have inherited and that we will pass on to future generations is a subject of critical concern. The loss of the 'public landscape', the sense of shared places and purposes that build convivial communities, is also concerning. In particular, water shore areas are attractive for private investors to build luxury residences and close the water from public access. Water shores are important for promenades, which explains why parks are being built in such areas, but in some cases also for bathing, a component of urban health (Kósa, 1999). Urban planning along the Danube had to be adapted for the buildings of public thermal bathes serving health treatments from Turkish times, with Art Nouveau and even contemporary buildings (Meder, 2011). Bathing might also be a religious purification ritual. Extending the interpretation of urban health to these concepts extends green infrastructure to blue-green infrastructure. The landscape architect must also configure areas along rivers to protect the surroundings from flood, thereby protecting urban health and life (Prominski et al., 2012).

These are only a few of the many issues that need to be addressed if the nature of landscape architecture and other allied practices concerned with the maintenance and management of our landscape is to remain relevant in the next century (Jacobs and Mann, 2000). To reconcile landscape conservation with changing demands on land use and natural resources, it is essential that the ecological, socio-cultural and economic values of the landscape be fully taken into account in planning and decision making (Groot, 2006). Decision making for landscape planning, conservation and management uses the concept of sustainability widely. To make it operational, many new associated and more specific concepts have been proposed, such as natural and social capital, conservation economy and quality of life capital. As landscape changes, its meaning, its significance and, consequently, its management also change (Antrop, 2006).

\section{Final remarks}

\subsection{Livable cities and environmental quality}

To attain the goal of a livable city, a wide range of social, economic and environmental needs must be satisfied (Pacione, 2003a,b). Social viewpoints such as employment, education and safety have recently been given much attention in the development of indicators of urban livability. In addition, environmental aspects, such as clean air, a quiet neighborhood, an attractive street scene and green spaces within walking distance, are gaining weight (Fig. 2). The amount and quality of green spaces affect citizens' patterns of activities, the modes and frequencies of everyday recreation, the way knowledge about the environment is acquired, and opportunities to relax and cope with daily stress (Van Herzele and Wiedemann, 2003).

The presence of natural areas contributes to quality of life through environmental and ecological services (Chiesura, 2004). Environmental quality specialists play an important role in providing tools that can measure and compare, both in sum and distributively across different groups, the environmental quality implications of different futures (Brown, 2003). Concepts such as livability, living quality, living environment, quality of place, residential perception and satisfaction, the evaluation of residential and living environments, quality of life and sustainability are often used as synonyms and do in fact overlap-but every so often, they contrast with another (Van Kamp et al., 2003). The quality of urban soil should be evaluated to support public services for good environmental quality management. Planners should also adjust their decisions towards more sustainable urban design (Vrščaj et al., 2008).

\subsection{Urban development and growth}

Four out of five European citizens live in urban areas, and urban form - such as the density or compactness of a city - influences daily life and is an important factor for both quality of life and environmental impact. An interdisciplinary study of urban form including landscape metrics, socio-economic factors and governance structures combined with a historical analysis would greatly enhance understanding of the emerging urban form (Schwarz, 2010).

Monitoring urban development to assure cities are sustainable in the future is an absolute necessity. Decision support in this domain requires spatial information for forecasting urban development trends (Weber, 2003). Analyzing the factors that condition 


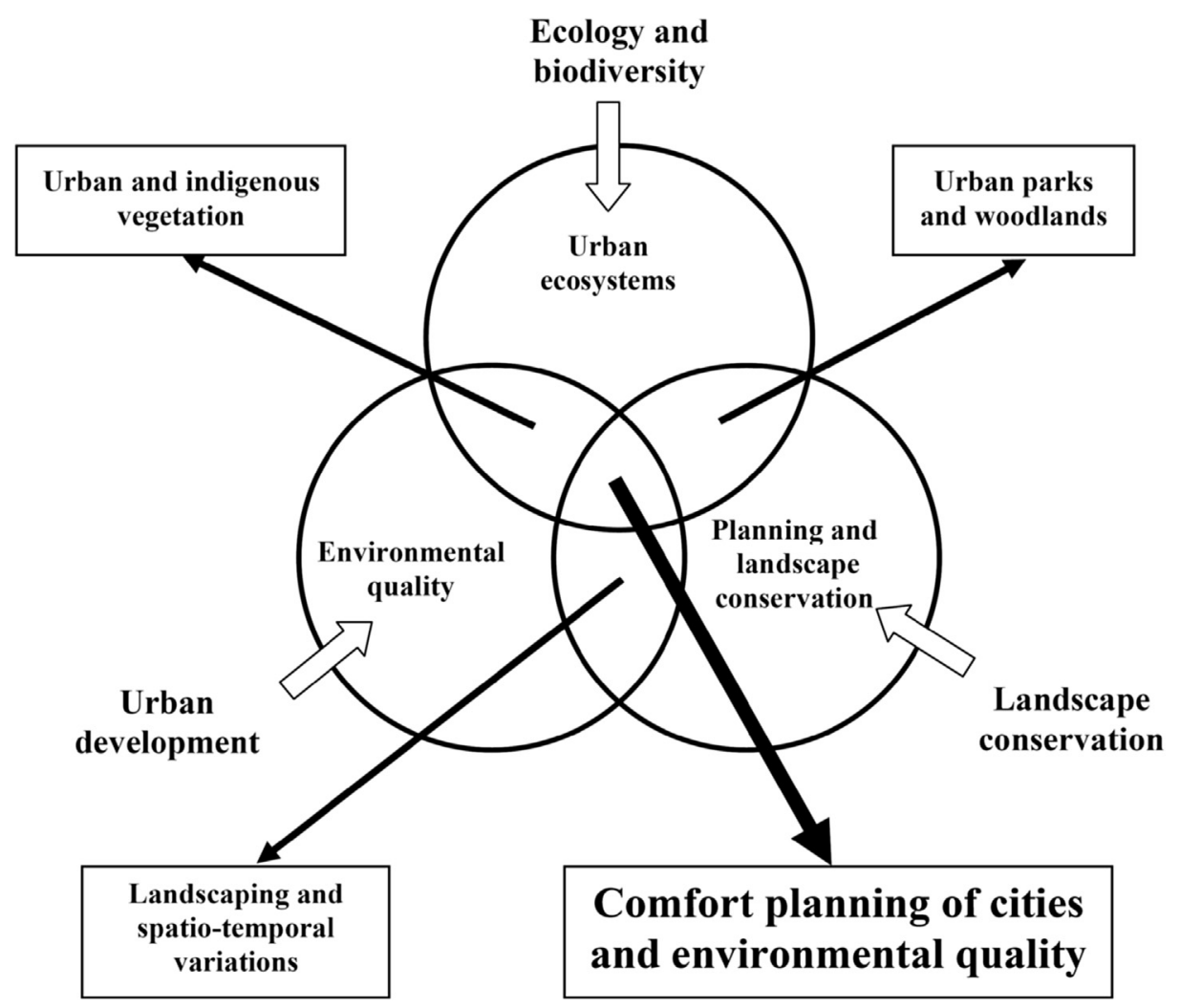

Fig. 2. Comfort planning of cities and environmental quality.

walking in an urban environment is another important task in urban planning. The landscape, in its entirety, plays a role in encouraging pedestrian movement. The frequency of pedestrian traffic in the streets has been analyzed as a function of accessibility and landscape preferences with the help of a conceptual framework (Foltête and Piombini, 2007). The capacity to project urban growth scenarios reflecting various public policies so that their relative impacts on natural resources can be evaluated has been broadly discussed (Beardsley et al., 2009). In addition, GIS tools such as SpaceSyntax (Hillier, 2007) can be employed to observe flows in urban public space and judge the accessibility of urban green areas and water.

\subsection{Human health and well-being}

The quality of the urban environment as a living space for the people of the world is an issue of fundamental concern for academic researchers, policy makers and citizens. Increasing concern over the nature and extent of socio-spatial divisions in urban environmental quality and human well-being has focused international research attention on the problems of living in a contemporary city (Pacione, 2003a,b). The identification of quantifiable landscape attributes that affect health is seen as an important factor for making future landscape design beneficial to human health (Velarde et al., 2007).

Sustainable development requires, among other things, that development projects not result in the degradation of natural resources for outdoor recreation. There has been a rapid increase in knowledge regarding the importance of the external environment to our health and well-being (Fig. 3). Urban forest investments for health and well-being can be an important part of strategic decisions in spatial planning. As preconditions for a permit, the development and financing of new urban forests and green areas should be a part of the overall development plan. This issue is of global interest, because many countries are in a process of rapid urbanization, and urban greening and urban forestry have an important role to play in the process of promoting quality of life and improving environmental quality (Skärbäck, 2007). In the case of shrinking cities, urban agriculture can be used as a policy to increase the quality of life for the remaining population (Panagopoulos et al., 2015).

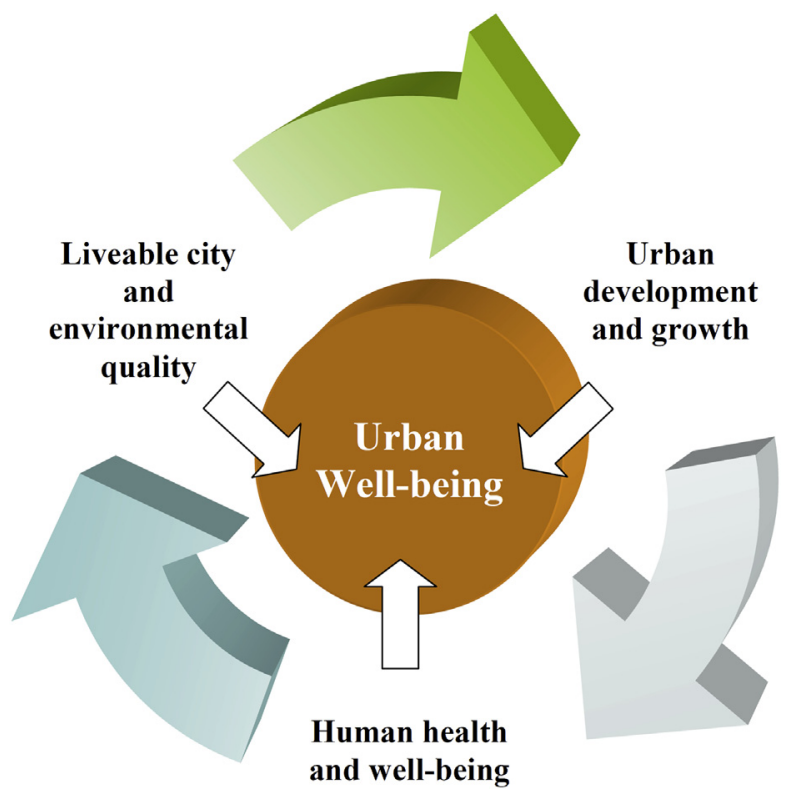

Fig. 3. Urban well-being and sustainable development. 
To many people, solitude and peacefulness are the main qualities of natural landscapes, especially woodlands, in relation to recovery from stress and attention fatigue (Busse and Nilsson, 2007). Research indicates a relationship between the sensory perception of natural environments and human health. Urban green spaces can be viewed as elements of importance to public mental health (Grahn and Stigsdotter, 2010). The present research suggests a multi-disciplinary approach to attaining a holistic understanding of urban environmental quality and human well-being in relation to sustainable urban development.

\section{Acknowledgments}

The authors want to thank the support of the Foundation for Science and Technology under grand UID/SOC/04020/2013 and COST Action FP1204: Green Infrastructure approach: linking environmental with social aspects in studying and managing urban forests, and the scholarship POSDRU/159/1.5/S/133391, for having provided the conditions to publish this work.

\section{References}

Antrop, M., 2005. Why landscapes of the past are important for the future. Landsc Urban Plan. 70, 21-34.

Antrop, M., 2006. Sustainable landscapes: contradiction, fiction or utopia? Landsc Urban Plan. 75, 187-197.

Armaş, I., Osaci-Costache, G., Braşoveanu, L., 2014. Forest landscape history using diachronic cartography and GIS. Case study: Subcarpathian Prahova valley, Romania. In: Crăciun, C., Bostenaru, D.M. (Eds.), Planning and Designing Sustainable and Resilient Landscapes. Springer, Dordrecht, pp. 73-86.

Beardsley, K., Thorne, J.H., Roth, N.E., Gao, S., McCoy, M.C., 2009. Assessing the influence of rapid urban growth and regional policies on biological resources Landsc. Urban Plan. 93, 172-183.

Berte, E., Panagopoulos, T., 2014. Enhancing city resilience to climate change by means of ecosystem services improvement: a SWOT analysis for the city of Faro Portugal. Int. J. Urban Sustain. Dev. 6, 241-253.

Bone, C., Dragićević, S., 2010. Incorporating spatio-temporal knowledge in an intelligent agent model for natural resource management. Landsc. Urban Plan. 96, 123-133.

Bostenaru, D.M. 2010. Spațiul Verde Redescoperit Der Wiederentdeckte Grünraum, Cuvillier, Göttingen.

Bostenaru, D.M., 2014. Innovative geotextile materials for the extension of urban green space-contribution to urban sustainability. Rev. Environ. Sci. Bio-Technology 13, 5-9.

Breuste, J., 2004. Decision making, planning and design for the conservation of indigenous vegetation within urban development. Landsc. Urban Plan. 68, $439-452$.

Brown, A.L., 2003. Increasing the utility of urban next term environmental quality information. Landsc. Urban Plan. 65, 85-93.

Brown, K.H., Jameton, A.L., 2000. Public health implications of urban agriculture. J. Public Health Policy 21, 20-39.

Buijs, A., Elands, B., Langers, F., 2009. Social interactions in urban parks: stimulating social cohesion? Urban For. Urban Green. 9, 93-100.

Busse, A., Møllerb, F., 2008. Is coppice a potential for urban forestry? The social perspective. Urban For. Urban Green. 7, 129-138.

Busse, A., Nilsson, K., 2007. Urban forestry for human health and wellbeing. Urban For. Urban Green. 6, 195-197.

Cameron, R.W.F., Blanusa, T., Taylor, J.E., Salisbury, A., Halstead, A.J., Henricot, B. Thompson, K., 2012. The domestic garden - its contribution to urban green infrastructure. Urban For. Urban Green. 11, 129-137.

Carles, J.L., López Barrio, I., de Lucio, J.V., 1999. Sound influence on landscape values. Landsc. Urban Plan. 43, 191-200.

Carmin, J., Nadkarni, N., Rhie, C., 2012. Progress and Challenges in Urban Climate Adaptaion Planning: Results from a Global Survey. MIT, Cambridge, MA.

Cavanagh, J.A., Zawar-Reza, P., Wilson, J.G., 2009. Spatial attenuation of ambient particulate matter air pollution within an urbanised native forest patch. Urban For. Urban Green. 8, 21-30.

Chiesura, A., 2004. The role of urban parks for the sustainable city. Landsc. Urban Plan. 68, 129-138.

Cook, E.A., 2002. Landscape structure indices for assessing urban ecological networks. Landsc. Urban Plan. 58, 269-280.

Costanza, R., Daly, H.E., 1992. Natural capital and sustainable development. Conserv. Biol. 6, 37-46.

Council of Europe, 2000. European Landscape Convention, Florence, Explanatory Report CETS No. 176. Council of Europe, Strasbourg.

Deng, J.S., Wang, K., Hong, Y., Qi, J.G., 2009. Spatio-temporal dynamics and evolution of land use change and landscape pattern in response to rapid urbanization. Landsc. Urban Plan. 92, 187-198.
Eliasson, I., 2000. The use of climate knowledge in urban planning. Landsc. Urban Plan. 48, 31-44.

Escobedo, F.J., Nowak, D.J., 2009. Spatial heterogeneity and air pollution removal by an urban forest. Landsc. Urban Plan. 90, 102-110.

European Commission, 2006. Thematic Strategy for Soil Protection. Communication from the Commission to the Council, the European Parliament, the European Economic and Social Committee and the Committee of the Regions. COM (2006) 231 final, 22.9.2006. EC, Brussels, EU.

Foltête, J.C., Piombini, A., 2007. Urban layout, landscape features and pedestrian usage. Landsc. Urban Plan. 81, 225-234.

Francis, R.A., Lorimer, J., 2011. Urban reconciliation ecology: the potential of living roofs and walls. J. Environ. Manag. 92 (6), 1429-1437.

Geneletti, D., 2008. Incorporating biodiversity assets in spatial planning: methodological proposal and development of a planning support system. Landsc. Urban Plan. 84, 252-265.

Gidlöf-Gunnarsson, A., Öhrström, E., 2007. Noise and well-being in urban residential environments: the potential role of perceived availability to nearby green areas. Landsc. Urban Plan. 83, 115-126.

Goličnik, B., Thompson, C.W., 2010. Emerging relationships between design and use of urbannext term park spaces. Landsc. Urban Plan. 94, 38-53.

Gómez, F., Tamarit, N., Jabaloyes, J., 2001. Green zones, bioclimatics studies and human comfort in the future development of urban planning. Landsc. Urban Plan. 55, 151-161.

Gordon, A., Simondson, D., White, M., Moilanen, A., Bekessy, S.A., 2009. Integrating conservation planning and landuse planning in urban landscapes. Landsc. Urban Plan. 91, 183-194.

Grahn, P., Stigsdotter, U.K., 2010. The relation between perceived sensory dimensions of urban green space and stress restoration. Landsc. Urban Plan. 94, 264-275.

Groot, R., 2006. Function-analysis and valuation as a tool to assess land use conflicts in planning for sustainable, multi-functional landscapes. Landsc. Urban Plan. 75, 175-186.

Hall, L., 1995. Olmsted's America. An "Unpractical" Man and His Vision of Civilization. Bullfinch Press, Boston, MA.

Hernández, J., García, L., Ayuga, F., 2004. Assessment of the visual impact made on the landscape by new buildings: a methodology for site selection. Landsc. Urban Plan. 68, 15-28.

Hillier, B., 2007. Space Is the Machine: a Configurational Theory of Architecture. Space Syntax, London, UK.

INSPIRATION, 2015. Integrated Spatial Planning, Land Use and Soil Management Research Action. http://www.inspiration-h2020.eu/ (last accessed 7-7-2015).

Jackson, L.E., 2003. The relationship of urban design to human health and condition. Landsc. Urban Plan. 64, 191-200.

Jacobs, P., Mann, R., 2000. Landscape prospects of the next millennium. Landsc. Urban Plan. 47, 129-133.

Jankovska, I., Donis, J., Straupe, I., Panagopoulos, T., Kupfere, L., 2013. Assessment of forest recreation accessibility in Latvia. Fresenius Environ. Bull. 22, 2145-2151.

Jim, C.Y., Chena, W.Y., 2010. Habitat effect on vegetation ecology and occurrence on urban masonry walls. Urban For. Urban Green. 9, 169-178.

Karanikola, P., Panagopoulos, T., Tampakis, S., Karantoni, M.I., Tsantopoulos, G., 2014. Facing and managing natural disasters in the Sporades islands, Greece. Nat. Hazards Earth Syst. Sci. 14, 995-1005.

Koenigs, T. (Ed.), 1991. Vision Offener Grünräume: GrünGürtel Frankfurt. Campus Verlag, Frankfurt am Main.

Konijnendijk, C. Nielsen, A.B., Schipperijn, J., Rosenblad, Y., Sander, H., Sarv, M., Makinen, K., Tyrvainen, L., Donis, J., Gundersen, V., Akerlund, U., Gustavsson, R., 2007. Assessment of urban forestry research and research needs in Nordic and Baltic countries. Urban For. Urban Green. 6, 297-309.

Kósa, L., 1999. Badeleben und Kurorten in Österreich-Ungarn. Holnap Verlag, Budapest.

Loures, L., Loures, A., Nunes, J., Panagopoulos, T., 2015. Landscape valuation of environmental amenities throughout the application of direct and indirect methods. Sustainability 7, 794-810.

Matsuoka, R.H., Kaplan, R., 2008. People needs in the urban landscape: analysis of landscape and urban planning contributions. Landsc. Urban Plan. 84, 7-19.

Meder, I., 2011. Badefreuden. Metro Verlag, Vienna.

National Geographic, 2012. http://www.natgeo.ro/natura/habitat-conservare/9690delta-dintre-blocuri (last accessed 12-7-2014)

Oh, K., Jeong, S., 2007. Assessing the spatial distribution of urban parks using GIS. Landsc. Urban Plan. 82, 25-32.

Pacione, M., 2003a. Introduction on urban environmental quality and human wellbeing. Landsc. Urban Plan. 65, 1-3.

Pacione, M., 2003b. Urban environmental quality and human wellbeing-a social geographical perspective. Landsc. Urban Plan. 65, 19-30.

Panagopoulos, T., 2009. Linking forestry, sustainability and aesthetics. Ecol. Econ. 68, 2485-2489.

Panagopoulos, T., Guimaraes, M.E., Barreira, A.P., 2015. Influences on citizens' policy preferences for shrinking cities: a case study of four Portuguese cities. Reg. Stud. Reg. Sci. 2, 140-169.

Petrosillo, I., Zaccarelli, N., Semeraro, T., Zurlini, G., 2009. The effectiveness of different conservation policies on the security of natural capital. Landsc. Urban Plan. 89, 49-56.

Poggio, L., Vrščaj, B., Hepperle, E., Schulin, R., Ajmone Marsan, F., 2008. Introducing a method of human health risk evaluation for planning and soil quality management of heavy metal-polluted soils-an example from Grugliasco (Italy). 
Landsc. Urban Plan. 88, 64-72.

Popa, A., 2014. Decoding agricultural landscape. In: Crăciun, C., Bostenaru, D.M. (Eds.), Planning and Designing Sustainable and Resilient Landscapes. Springer, Dordrecht, pp. 33-41.

Potschin, M.B., Haines-Young, R.H., 2006. Landscapes and sustainability. Landsc. Urban Plan. 75, 155-161.

Prominski, M., Stokman, A., Stimberg, D., Voermanek, H., Zeller, S., 2012. Fluss Raum Entwerfen: Planungsstrategien für urbane Fließgewässer. Birkhäuser, Munich.

Rockström, J., Steffen, W., Noone, K., Persson, Å., Chapin, F.S., Lambin, E.F. Lenton, T.M., Scheffer, M., Folke, C., 2009. A safe operating space for humanity. Nature 461 (7263), 472-475.

Rodiek, J., 2008. Protecting ecosystems and open spaces in urbanizing environments. Landsc. Urban Plan. 84, 3-6.

Sandström, U.G., Angelstam, P., Khakee, A., 2006. Urban comprehensive planning identifying barriers for the maintenance of functional habitat networks. Landsc. Urban Plan. 75, 43-57.

Scalenghe, R., Marsan, F.A., 2009. The anthropogenic sealing of soils in urban areas. Landsc. Urban Plan. 90, 1-10.

Schindelbeck, R.R., van Es, H.M., Abawi, G.S., Wolfe, D.W., Whitlow, T.L., Gugino, B.K., Idowu, O.J., Moebius-Clune, B.N., 2008. Comprehensive assessment of soil quality for landscape and urban management. Landsc. Urban Plan. 88, 73-80.

Schwarz, N., 2010. Urban form revisited-Selecting indicators for characterising European cities. Landsc. Urban Plan. 96, 29-47.

Siminea, I., Bostenaru, M., 2000. Sowed biodegradable geotextile for fixing the ash dump of coal and preventing environmental pollution. In: Proceedings of the 2nd European Geosynthetics Conference, Bologna, Italy, 15-18 October 2000, pp. 915-918.

Skärbäck, E., 2007. Urban forests as compensation measures for infrastructure development. Urban For. Urban Green. 6, 279-285.

Smardon, R.C., 1988. Perception and aesthetics of the urban environment: review of the role of vegetation. Landsc. Urban Plan. 15, 85-106.

Stan, A., 2014. The landscape of the urban peripheries: an alternative therapy. In: Crăciun, C., Bostenaru, D.M. (Eds.), Planning and Designing Sustainable and Resilient Landscapes. Springer, Dordrecht, pp. 117-126.

Stephenson, J., 2008. The cultural values model: an integrated approach to values in landscapes. Landsc. Urban Plan. 84, 127-139.
Styers, D.M., Chappelka, A.H., Marzen, L.J., Somer, G.L., 2010. Developing a landcover classification to select indicators of forest ecosystem health in a rapidly urbanizing landscape. Landsc. Urban Plan. 94, 158-165.

Taylor, P.D., 2002. Fragmentation and cultural landscapes: tightening the relationship between human beings and the environment. Landsc. Urban Plan. 58 , 93-99.

Thorne, J.F., Huang, C.S., 1991. Toward a landscape ecological aesthetic: methodologies for designers and planners. Landsc. Urban Plan. 21, 61-79.

Tratalos, J., Fuller, R.A., Warren, P.H., Davies, R.G., Gaston, K.J., 2007. Urban form, biodiversity potential and ecosystem services. Landsc. Urban Plan. 83, 308-317.

Tyrväinen, L., Mäkinen, K., Schipperijn, J., 2007. Tools for mapping social values of urban woodlands and other green areas. Landsc. Urban Plan. 79, 5-19.

Tzoulas, K., Korpela, K., Venn, S., Yli-Pelkonen, V., Kazmierczak, A., Niemela, J., James, P., 2007. Promoting ecosystem and human health in urban areas. Landsc. Urban Plan. 81, 167-178.

Van Herzele, A., Wiedemann, T., 2003. A monitoring tool for the provision of accessible and attractive urban green spaces. Landsc. Urban Plan. 63, 109-126.

Van Kamp, I., Leidelmeijer, K., Marsman, G., Hollander, H., 2003. Urban environmental quality and human well-being: towards a conceptual framework and demarcation of concepts; a literature study. Landsc. Urban Plan. 65, 5-18.

Velarde, M.D., Fry, G., Tveit, M., 2007. Health effects of viewing landscapes landscape types in environmental psychology. Urban For. Urban Green. 6, $199-212$.

Vrščaj, B., Poggio, L., Ajmone Marsan, F., 2008. A method for soil environmental quality evaluation for management and planning in urban areas. Landsc. Urban Plan. 88, 81-94.

Wang, Z., 2009. Bridging urban planning and ecology. Landsc. Urban Plan. 92, $348-350$

Weber, C., 2003. Interaction model application for urban planning. Landsc. Urban Plan. 63, 49-60.

Willemen, L., Verburg, P.H., Hein, L., van Mensvoort, M.E.F., 2008. Spatial characterization of landscape functions. Landsc. Urban Plan. 88, 34-43.

Wolch, J.R., Byrne, J., Newell, J.P., 2014. Urban green space, public health, and environmental justice: the challenge of making cities 'just green enough'. Landsc. Urban Plan. 125, 234-244. 